Обзоры

(C) Чекнёв С.Б., 2021

Чекнёв С.Б.

Белки $\gamma$-глобулиновой фракции, хелатирующие катионы металлов, в физиологической иммунорегуляции. Оппозитные эффекты меди и цинка

Федеральное государственное бюджетное учреждение «Национальный исследовательский центр эпидемиологии и микробиологии имени почетного академика Н.Ф. Гамалеи» Министерства здравоохранения Российской Федерации, 123098, г. Москва, Российская Федерация

\title{
Резюме
}

В работе обобщаются результаты исследований, свидетельствующие о том, что в условиях нормального физиологического обмена белки $\gamma$-глобулиновой фракции плазмы крови хелатируют из периглобулярного пространства катионы металлов и претерпевают вследствие этого конформационные преобразования, преимущественно затрагивающие структуры их Fc-фрагмента. В результате таких преобразований меняется динамика взаимодействия $\gamma$-глобулинов с Fc-рецепторами (FcR), экспрессированными на поверхности клеток иммунной системы, возникают изменения внутриклеточной сигнализации, замкнутой на активацию FcR, и клеточных ответов, запускаемых сигнальной трансдукцией, индуцируемой FcR. Хелатируемые белками $\gamma$-глобулиновой фракции и локализуемые в молекулах антител специфическими по топике распределения сайтами связывания, катионы меди и цинка вызывают оппозитные изменения эффекторных свойств $\gamma$-глобулинов, проявляющиеся реципрокным изменением клеточных функций в ответ на активацию FcR трансформированными металлом белками. При этом на уровне физиологической регуляции связывающие единичные катионы меди и цинка $\gamma$-глобулины, peализуя оппозитные свойства, поддерживают определенную напряженность клеточного иммунитета, исключая возможность срыва толерантности и повреждения собственных неизмененных клеток организма.

Ключевые слова: $\gamma$-глобулины; катионы металлов; хелатирование; оппозитные свойства

Статья получена 17.03.2021. Принята в печать 20.04.2021.

Для цитирования: Чекнёв С.Б. Белки $\gamma$-глобулиновой фракции, хелатирующие катионы металлов, в физиологической иммунорегуляции. Оппозитные эффекты меди и цинка. Иммунология. 2021; 42 (3): 293-300. DOI: https://doi.org/10.33029/0206-4952-2021-42-3-293-300

Финасирование. Исследование выполнено в рамках государственного задания Минздрава России «Молекулярные и клеточные основы противоинфекционной иммунорезистентности», шифр тематики К-32-НИР/112, регистрационный номер 01201255945 от 4 апреля 2012 г.

Конфликт интересов. Автор заявляет об отсутствии конфликта интересов.

\section{Cheknev S.B.}

\section{The proteins of $\gamma$-globulin fraction, that bind metal ions, in physiological immune regulation. Opposite effects of copper and zinc}

N.F. Gamaleya National Research Centre for Epidemiology and Microbiology of the Ministry of Health of the Russian Federation, 123098, Moscow, Russian Federation
Abstract
The data summarized in the paper concerning possibility of metal ions chelation by proteins of human $\gamma$-globulin blood plasma fraction from their periglobular space and of conformational changes dealing with such a binding in normal physiological conditions that primarily cause the shifts in Fc-fragment structures. As a result of such shifts dynamics of interactions of $\gamma$-globulins with Fc-receptors (FcR) expressed on the surface of immune system cells does 
change, and intracell signaling caused by FcR activation as well as cell responses induced by signal transduction from FcR do also shift. Copper and zinc ions bound by $\gamma$-globulin fraction proteins and localized within antibodies molecules by specifically distributed by their topics binding sites cause opposite changes of effector properties of $\gamma$-globulins that reciprocally shift cell functions in response to FcR activation by the proteins transformed with metal binding. In physiological immune regulation the proteins of $\gamma$-globulin fraction chelating the single copper and zinc ions and exerting thereby opposite effector properties support induction of cellular immunity simultaneously excluding the tolerance burst and pathological reactions towards own normal human cells.

Keywords: $\gamma$-globulins; metal ions; chelation; opposite properties

Received 17.03.2021. Accepted 20.04.2021.
For correspondence

Sergey B. Cheknev - MD, PhD,

Deputy Director for Science,

N.F. Gamaleya NRCEM of the $\mathrm{MOH}$ of Russia, Moscow, Russian Federation

E-mail: cheknev@gamaleya.org http://orcid.org/0000-0002-9512-7148

For citation: Cheknev S.B. The proteins of $\gamma$-globulin fraction, that bind metal ions, in physiological immune regulation. Opposite effects of copper and zinc. Immunologiya. 2021; 42 (03): 293-300. DOI: https://doi.org/10.33029/02064952-2021-42-3-293-300 (in Russian)

Funding. The study was performed in the frame of State task of the Ministry of Health of the Russian Federation «Molecular and cellular basis for the antiinfectional immune resistance» K-32-NIR/112, registration number 01201255945 of the $4^{\text {th }}$ of April, 2012

Conflict of interests. Author declares no conflict of interests.

\section{Введение}

Комплексом фундаментальных исследований, реализованным в течение двух последних десятилетий, сформирована совокупность принципиально новых представлений о месте и роли катионов металлов в физиологической иммунорегуляции и контроле клеточных функций [1-11]. В соответствии с этими представлениями наряду с прямым действием катионов на определенные внутриклеточные сигнальные пути, неменьшую значимость в физиологических обменных процессах обретает способность металлов хелатироваться белками плазмы крови, находящимися в циркуляции, и вызывать посредством изменения их конформационных характеристик реализацию измененных или возникновение новых эффекторных свойств в отношении лимфоцитов человека. Непременным условием осуществления указанных регуляторных воздействий выступает экспрессия клетками иммунной системы специфических рецепторов белков плазмы, запускающих трансдукцию сигналов во внутриклеточные компартменты.

Доказательная база исследования выстраивалась последовательной реализацией отдельных взаимодействий, воспроизводящих хелатирование белком металла, конформационные преобразования белковой молекулы, изменение динамики связывания с рецептором клетки, изменение клеточных функций. Для объективной оценки событий на каждом этапе исследования отрабатывалась совокупность прямых и косвенных методических приемов и подходов, позволявших получать не только качественные, но и количественные характеристики описываемых реакций и клеточных ответов, сопровождать постановки необходимыми контролями, определяющими специфичность по белку или по металлу, а изменения клеточных ответов - в динамике их осуществления.
Конформационные преобразования хелатирующего металл белка оценивали с использованием дифференциальной спектрофотометрии в ультрафиолете, количество связавшегося с белком металла определяли с помощью специфических реакций комплексообразования, возможность изменения антигенных характеристик молекулы белка в результате связывания металла проверяли, анализируя поверхностное распределение специфических антигенных детерминант с использованием реакций одно- и двухмерной радиальной иммунодиффузии, а также прямого и «сэндвич»-вариантов иммуноферментного анализа (ИФА) со специфическими мечеными антителами.

Изменение клеточных функций в условиях воздействия конформационно трансформированных металлом белков оценивали, определяя выработку клетками периферической крови (КПК) человека интерферона(ИФН)- $\alpha$ и ИФН- $\gamma$ (биологическая активность и ИФА), а также спектра основных иммуноактивных цитокинов, ответственных за поляризацию иммуногенеза и реализацию воспаления (ИФА), отслеживали экспрессию генов этих цитокинов в мононуклеарных клетках методами амплификации (полимеразная цепная реакция). В отдельных экспериментах оценивали пролиферативную активность спленоцитов мышей (реакции спонтанной и индуцированной митогеном бласт-трансформации - РБТ) и цитотоксическую активность естественных киллеров (НК-клеток) в суспензии спленоцитов мышей против меченных изотопом клеток перевиваемой линии мышиных фибробластов L929. Свидетельства реализации эффектов посредством модификации связывания трансформированного металлом белка с его рецептором на поверхности клетки получали, применяя блокирование клеточного рецептора специфическим лигандом.

Объектом исследований служил сывороточный $\gamma$-глобулин человека - белковая фракция плазмы крови, составляющая до 10-12 \% общего белка и включающая 
до 72-84 \% иммуноглобулинов класса G (IgG), запускающих реализацию внутриклеточных сигнальных путей посредством связывания с экспрессируемыми клеткой рецепторами к их Fc-фрагменту (Fc $\gamma \mathrm{R})$.

В качестве хелатируемых и меняющих конформационное состояние белка металлов исследовали катионы меди $\left(\mathrm{Cu}^{2+}\right)$ и цинка $\left(\mathrm{Zn}^{2+}\right)$ - достаточно крупные, чтобы их эффекты могли регистрироваться относительно простыми методами, известные способностью к активному комплексообразованию с одинаковой геометрией окружения лигандами и высокой аффинностью взаимодействия с белками, имеющие сходные электронные конфигурации и близкие ионные радиусы и в силу этого часто реализующие в биологических системах оппозитные свойства в соответствии с известными законами биологической и физической химии. Эти металлы постоянно присутствуют в нормальной плазме крови человека, циркулируя в связанном с белками, гликопротеинами и аминокислотами (до 10-20 мкM $\mathrm{Cu}^{2+}$ и $\mathrm{Zn}^{2+}$ ) или даже в свободном гидратированном (до 0,2-1,0 нM Zn ${ }^{2+}$ ) состоянии, и не имеют в условиях обменных процессов никаких термодинамических запретов или стерических ограничений на хелатирование, реализующееся посредством образования новых координационных связей и в высокой степени энергетически выгодное.

В контексте рассматриваемых в данной публикации оппозитных свойств $\mathrm{Cu}^{2+}$ и $\mathrm{Zn}^{2+}$ эти металлы, параллельно проведенные через все экспериментальные постановки, служили адекватным контролем друг другу, обнаруживая специфичность или неспецифичность взаимодействия. Аналогично анионы $\mathrm{SO}_{4}^{2-}$ и $\mathrm{Cl}^{-}$в составе соли металла, тоже проведенные через все постановки препаративного и физико-химического этапов исследования, выступали по отношению друг к другу в качестве контролей, позволяющих отбирать адекватный состав солей для планирования и осуществления последующих этапов работы.

В течение 2006-2013 гг. результаты исследования регулярно публиковались в ведущих отечественных научных журналах с соблюдением необходимых объемов цитирования первичного материала, представлялись научному сообществу на крупных российских и международных научных форумах по иммунологии, составили основу трех методических разработок по совершенствованию существующих технологий в области иммунохимии и химии белка. Поскольку названные периодические публикации легко обнаруживаются по предметным или авторским указателям и доступны для ознакомления, в списке литературы к данной работе приведены только публикации, имеющие принципиальную значимость для методологического представления материала [1-11].

\section{Структурные и функциональные основы обмена металлов в микроокружении клетки}

Сегодня хорошо известно, что обмен ионами металлов между биомакромолекулами в окружении лимфоцита и самим лимфоцитом служит важным фактором регуляции активности клетки.
В микроокружении лимфоцита, находящегося в циркуляции или локализованного в тканевых компартментах, постоянно присутствует пул биологически активных макромолекул, которые конформированы углеводными компонентами, участвующими в образовании комплексных связей и металлосвязывающих сайтов, способны к хелатированию металлов и различаются по насыщенности катионами.

В ходе нормального межмолекулярного обмена такие макромолекулы могут хелатировать или донорствовать катионы металлов, в одном случае создавая дефицит катионов в микроокружении лимфоцита, в другом избыток ионов металла. Если при этом функции клетки реализуются как металлозависимые (а у лимфоцитов к этой категории можно отнести большую часть функционального потенциала), дефицит катионов будет способствовать ослаблению замкнутых на ион металла клеточных функций, а избыток ионов металла должен вызывать усиление специализированной активности клетки. Белки $\gamma$-глобулиновой фракции выступают естественным компонентом такой регуляции, поскольку их конформационные преобразования, связанные с хелатированием или донорствованием катионов, могут реализоваться в ходе нормальных межмолекулярных взаимодействий.

Сразу следует сделать два общих замечания, важных для последующего анализа материала и понимания логики построения исследования. Первое: как уже упоминалось выше, работа ориентирована на физиологические межмолекулярные взаимодействия, осуществляемые в режиме нормального обмена ионами металла, на базальные уровни клеточной активности, реализуемой в отсутствие какой-либо индукции, за исключением влияния самих белков $\gamma$-глобулиновой фракции и их металлокомплексов, на те реакции клеток, которыми обеспечивается отвечаемость лимфоцитов в условиях антигенной нагрузки или митогенной стимуляции. Под эти базовые уровни клеточной активности подбирали концентрационные и температурные диапазоны, контролировали отсутствие изменений антигенных свойств белков, что могло бы создавать возможность возникновения индуцирующих функции клетки эффектов, проверяли отсутствие токсичности получаемых макромолекул в отношении клеток человека. И второе: катионы металлов исследовали как факторы, вызывающие конформационные преобразования белков $\gamma$-глобулиновой фракции, т. е. в хелатированном белком состоянии. Прямое действие ионов металлов на клетку не служило предметом исследования, но обязательно оценивалось в качестве соответствующего контроля. В специальных экспериментах проверяли стабильность образующихся металлокомплексов, контролировали возможность десорбции катионов присоединившим металл белком.

Первичными хелаторами единичных катионов в структуре молекул белков $\gamma$-глобулиновой фракции, являющихся по своей природе, как и другие внеклеточные белки, полидентатными лигандами, выступают 


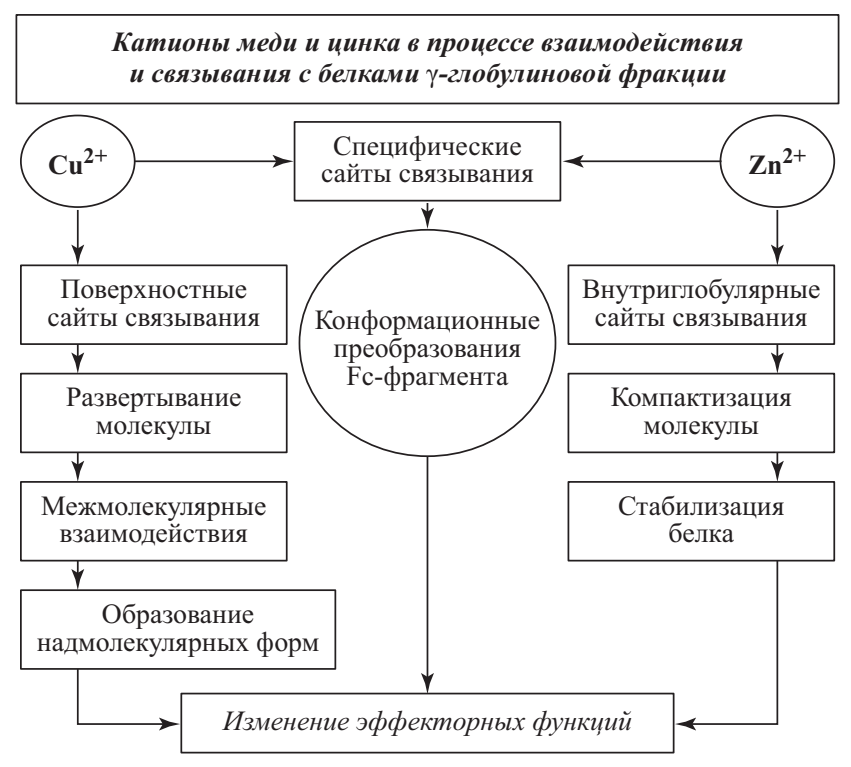

Рис. 1. Эффекты взаимодействия и связывания $\mathrm{Cu}^{2+}$ и $\mathrm{Zn}^{2+}$ с белками $\gamma$-глобулиновой фракции

разветвленные антенны олигосахаридов, ковалентно присоединенные к остатку аспарагина Asn297 тяжелой цепи $\mathrm{IgG}$ и экспонированные в шарнирной области молекулы. Сильный отрицательный заряд их вар-фракции привлекает из периглобулярного пространства отдельные катионы металлов и способствует связыванию катионов, которые частично нейтрализуют заряд сахаров. Утрачивающие присущую им высокую степень нуклеофильности олигосахаридные цепочки проявляют тенденцию к подворачиванию в более гидрофобные области междоменного пространства и увлекают за собой связанный ими ион металла. Последний оказывается погружен внутрь белковой глобулы, где, реализуя свой высокий потенциал комплексообразователя, реаранжирует поле тропных к нему лигандов, образует совокупность новых для хелатора координационных связей, встраивается в молекулу белка и компактизует глобулу $[1,2]$.

Вместе с тем третичная структура таких сложных белковых комплексов, как $\gamma$-глобулины, предполагает возможность формирования металлосвязывающих сайтов и на поверхности молекулы белка, достаточно равномерно (за исключением шарнирной области) распределяющей отрицательный заряд полярных боковых аминокислотных радикалов, моно- и дисахаридов, сиаловых кислот. В этом случае присоединение металла, располагающего гидратной оболочкой и сохраняющего взаимодействие с диполями воды, а также с ионным составом раствора, на внешние, открытые сайты связывания, не имеющие возможности подворачиваться в более гидрофобные внутренние области молекулы белка, декомпактизует глобулу, способствуя развертыванию молекулы белка в периглобулярное пространство [1].

Отслеженная динамика процесса показывает, что первые катионы встраиваются во внутренние компарт- менты молекулы белка, после насыщения которых взаимодействие переходит на внешние сайты связывания. Заполнение последних металлом с поэтапным развертыванием молекулы белка в водную (солевую) среду раствора создает условия экспонирования из внутренних областей молекулы исходно недоступных металлу сайтов связывания. Металл снова уходит во внутренние компартменты молекулы белка, глобула испытывает вторичную компактизацию, по завершении которой в условиях полного насыщения внутриглобулярных сайтов связывания взаимодействие возвращается на внешние связи молекулы, вторично развертывая уже полностью насыщенную металлом молекулу белка [2].

Сравнительная оценка способности $\mathrm{Cu}^{2+}$ и $\mathrm{Zn}^{2+}$ взаимодействовать с белками $\gamma$-глобулиновой фракции обнаруживает, что $\mathrm{Cu}^{2+}$, имеющий больший, чем у $\mathrm{Zn}^{2+}$, ионный радиус и менее концентрированный заряд, проявляющий меньшую химическую стабильность, реализует свойства редокс-активного металла, выступающего в биологических системах мощным окислителем, и взаимодействует с молекулой белка преимущественно по внешним, открытым сайтам связывания. Хелатирование $\mathrm{Cu}^{2+}$ может вызывать частичное расщепление боковых аминокислотных радикалов, сахаров и сиаловых кислот, аранжирующих поверхность макромолекулы, и деструктурирование пространственной упаковки поверхностного слоя, включая специфические (в том числе конформационные) антигенные детерминанты, локализованные на поверхности и экспонированные в микроокружение [3, 4]. Катионы цинка в редокс-обмене не активны, в окислительно-восстановительные реакции не вовлечены, в биологических системах выступают стабилизаторами макромолекул и биологических мембран. Обладающие высоким сродством к тиоловым группировкам внутриглобулярных компартментов ионы $\mathrm{Zn}^{2+}$ преимущественно встраиваются во внутримолекулярные области, замыкают на себя внутренние сайты связывания, специфически компактизуют глобулу и стабилизируют молекулу белка в новом конформационном состоянии, сопряженном с подворачиванием части специфических антигенных детерминант поверхности во внутренние области белковой глобулы $[1,2,5]$ (см. схему на рис.1).

При этом увлекаемые разветвленными антеннами олигосахаридов вар-фракции во внутренние области молекулы белка попадают и встраиваются там первые катионы и $\mathrm{Zn}^{2+}$, и $\mathrm{Cu}^{2+}$ - с последующим, в соответствии с отмеченными выше закономерностями, распределением по определенному числу внутренних и внешних сайтов связывания, формирующих несколько групп неэквивалентных и зависимых друг от друга участков присоединения ионов металла, заполняемых последовательно, по мере увеличения количества катионов $\mathrm{Cu}^{2+}$ или $\mathrm{Zn}^{2+}$, связавшихся с белком $[1,2]$. Это положение согласуется со случайным характером взаимодействия в физиологических условиях $\gamma$-глобулинов с катионами металлов - оказывающимися внутри молекулы 
белка исключительно благодаря привлекающему их в пределы шарнирной области высокому отрицательному заряду экспонированных здесь сахаров. А поскольку практически вся внутренняя пространственная упаковка междоменной области Fc-фрагмента организуется кор-фракцией олигосахаридов, ковалентно присоединенных, как отмечено выше, к аспарагиновым остаткам тяжелых цепей, понятно, что в условиях хелатирования металла $\gamma$-глобулинами первичным конформационным преобразованиям будут подвергаться структуры Fc-фрагментов антител. Возможные структурные перестройки Fab-фрагмента оказываются при этом вторичными по отношению к изменениям Fc-фрагмента [4].

Сказанное означает, что естественным следствием связывания белком катиона металла, с необходимостью меняющего конформационное состояние Fc-фрагмента, становится изменение динамики взаимодействия клеточных Fc $\gamma \mathrm{R}$ с белками $\gamma$-глобулиновой фракции, замыкаемого, как известно, локальными контактами, эллиптически распределенными в области нижнего, а по некоторым данным - и верхнего хинджа. Создавая новую пространственную упаковку Fc-фрагмента, посредством изменения динамики лиганд-рецепторного взаимодействия, хелатирование $\gamma$-глобулинами катионов металлов может приводить, следовательно, к изменению клеточных ответов на действие белков $\gamma$-глобулиновой фракции или реализации новых эффекторных свойств таких белков, запускающих внутриклеточную сигнализацию, активируемую Fc $\gamma \mathrm{R}$.

Независимо от того, какие бы сайты связывания белком иона металла (внешние или внутриглобулярные) не вовлекались преимущественно во взаимодействие, в молекуле белка, в направлении от Fc-фрагмента к Fab-фрагментам инициируется поток конформационных сигналов, распространяющихся по всей молекуле, включая шарнирную область и Fab-фрагменты, что обусловливает возникновение нового, динамически меняющегося конформационного состояния молекулы белка и не может не проявляться в обретении молекулой новых эффекторных функций (или модификацией реализуемых белком в его нативной конформации) в отношении экспрессирующих Fc $\gamma \mathrm{R}$ клеток человека [4] (см. рис. 1).

В широком смысле речь идет о сигнальной трансдукции, запускаемой активацией клеточных Fc $\gamma \mathrm{R}$ и реализуемой через семейство SRC-, SYK- и MAPKкиназ, участвующих в индукции процессов фагоцитоза, реакций окислительного взрыва и антителозависимой клеточно-опосредованной цитотоксичности, а также определяющих выработку клеткой всего спектра иммунорегуляторных цитокинов и хемокинов.

Конечно, полученные нами в исследовании константы связывания белком ионов металла относительно невысоки и $\gamma$-глобулины не могут рассматриваться в качестве хелаторов, сопоставимых по способности связывать катионы с такими специализированными переносчиками $\mathrm{Cu}^{2+}$ и $\mathrm{Zn}^{2+}$, как транскупреин или ме- таллотионеины соответственно [2]. Но в силу особенностей пространственной организации вторичной и третичной структуры белков $\gamma$-глобулиновой фракции рассчитанные стандартными методами характеристики позволяют описать лишь внешние сайты связывания, которые в условиях межмолекулярного обмена ионами металла могут донорствовать катионы более мощным хелаторам. Наличие у $\gamma$-глобулинов неполностью компактизованного междоменного пространства, в которое погружается связываемый ион металла, формирующий внутри белковой глобулы поле (или поля) тропных к нему лигандов, создает условия исключения связываемых катионов из свободного межмолекулярного обмена. Такое связывание не описывается расчетами стандартных констант, металл оказывается недоступным для физиологических обменных процессов и циркуляции, донорствование катионов становится возможно лишь вследствие активации протеолитических ферментов и катаболитного расщепления белка, сопровождающего уже не физиологические, а патологические реакции [2].

Установленная нами стабильность получаемых металлокомплексов позволяет методологически рассматривать $\gamma$-глобулины в качестве белков, способных захватывать, удерживать металл и выступать его переносчиками, пусть даже в локальном окружении. Сказанное означает, следовательно, что связавшие металл и трансформированные металлом белки могут опосредовать эффекты в отношении клеток человека дистантно от места хелатирования катионов [2].

Случайный характер физиологического хелатирования иона металла, позволяющий предсказывать эффекты трансформированного металлом белка лишь в вероятностных категориях, не исключает, тем не менее, возможного существенного вклада таких белков в регуляцию клеточных функций. Чувствительность реакции и использованных систем оценки достаточно высока, чтобы конформационные преобразования белковой глобулы, сопровождающиеся подворачиванием с поверхности (регистрация в «сэндвич»-варианте ИФА) определенной части специфических антигенных детерминант, обнаруживались уже при связывании одного катиона меди или цинка на молекулу белка, т. е. в условиях эквимолярного взаимодействия [5]. При этом, как показывают результаты наших иммунохимических исследований, образования новых антигенных детерминант белка и возникновения новой антигенной специфичности, которая могла бы индуцировать в организме выработку антител к собственному, связавшему металл и трансформированному металлом $\gamma$-глобулину, с большой вероятностью не происходит $[3,5]$.

На приведенных схемах металлосвязывающие сайты, инициирующие конформационные преобразования белковой глобулы, обозначены как специфические. Конечно, их нельзя полагать специфическими по составу и структуре, даже пространственная локализация в молекуле белка и определяемый ими вектор транспорта катионов не сообщают им специфических 


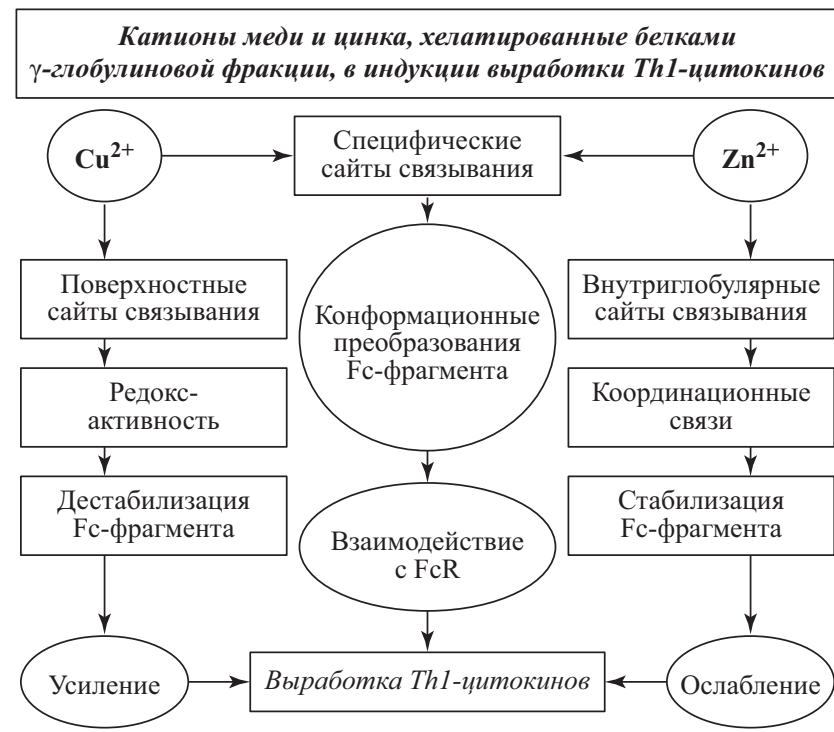

Рис. 2. Выработка Тh1-цитокинов в присутствии белков $\gamma$-глобулиновой фракции, трансформированных связыванием $\mathrm{Cu}^{2+}$ и $\mathrm{Zn}^{2+}$

характеристик. Вместе с тем, как будет видно из дальнейшего изложения, в системе взаимосвязей металлбелок-рецептор-клетка эффекты $\mathrm{Cu}^{2+}$ и $\mathrm{Zn}^{2+}$ оказываются оппозитными, а действие на клетку $\gamma$-глобулинов, трансформированных присоединением $\mathrm{Cu}^{2+}$ и $\mathrm{Zn}^{2+}$ - peципрокным. Следовательно, функциональная специфичность, определяемая направленностью изменения эффекторных функций белков $\gamma$-глобулиновой фракции, может оцениваться как абсолютная. При этом, в соответствии с полученными нами данными, $\gamma$-глобулины способны связывать большие количества металла из раствора с его меньшим содержанием [3].

\section{Катионы меди и цинка, хелатированные белками $\gamma$-глобулиновой фракции, в индукции выработки Th1-цитокинов}

В развитии иммунного ответа I типа хелатирование $\mathrm{Cu}^{2+}$ трансформирует белки $\gamma$-глобулиновой фракции плазмы в состояние, сообщающее им способность индуцировать выработку КПК человека больших, чем индуцируют исходные $\gamma$-глобулины, количеств ранних (24 ч индукции) интерлейкина(ИЛ)-2 и ИФН- $\gamma$. Присоединение $\mathrm{Zn}^{2+}$ снижает количество ранних ИЛ-2 и ИФН- $\gamma$, индуцируемых белками $\gamma$-глобулиновой фракции $[6,7]$. В динамике наблюдения, спустя 72 ч от старта инкубации, на уровне позднего ответа белковый комплекс с $\mathrm{Cu}^{2+}$ также индуцирует выработку КПК человека больших, чем под действием исходных $\gamma$-глобулинов, количеств ИФН- $\gamma$. Присоединение $\mathrm{Zn}^{2+}$ на 48 и 72 ч инкубации клеток снижает количество ИФН- $\gamma$, индуцируемого $\gamma$-глобулинами [7].

На эти же поздние сроки исследования в присутствии хелатировавшего $\mathrm{Cu}^{2+} \gamma$-глобулина усиливается зависящая от выработки ИЛ-2 спонтанная РБТ спленоцитов мышей, которая ослабляется белком, трансформирован- ным присоединением $\mathrm{Zn}^{2+}$ [8]. Схожие закономерности обнаруживаются в условиях митогенной нагрузки - при оценке РБТ спленоцитов животных, индуцированной конканавалином $\mathrm{A}$ : комплекс $\gamma$-глобулина с $\mathrm{Cu}^{2+}$ усиливает, а с $\mathrm{Zn}^{2+}$ - ослабляет индуцирующее клеточную пролиферацию действие фитомитогена [8].

Очевидно, что в индукции иммунного ответа I типа, реализуемого за счет выработки Тh1-цитокинов, локализуемая преимущественно поверхностными сайтами связывания медь проявляет свои редокс-активные и окислительные свойства, дестабилизирует структуры Fc-фрагмента, повышает пластичность молекулы белка в области контактов с Fc $\gamma \mathrm{R}$ и тем самым облегчает запуск сигнальной трансдукции, замкнутой на Fc $\gamma R$, обеспечивая усиление выработки КПК человека Th1-цитокинов (см. рис. 2). Трансформированные связыванием $\mathrm{Cu}^{2+}$ белки на уровне иммунного ответа I типа проявляют, следовательно, провоспалительные свойства.

Действуя за счет специфического внутреннего комплексообразования в качестве стабилизаторов биомакромолекул, катионы $\mathrm{Zn}^{2+}$ упорядочивают внутреннюю упаковку полипептидных цепей и повышают степень конформационной жесткости белковой глобулы. Пластичность структур молекулы белка в области контактов с клеточными Fc $\gamma \mathrm{R}$ при этом снижается, замкнутый на Fc $\gamma \mathrm{R}$ поток внутриклеточных сигналов ослабевает, выработка КПК человека Th1-цитокинов снижается (см. рис. 2). Трансформированные связыванием $\mathrm{Zn}^{2+} \gamma$-глобулины на уровне иммунного ответа I типа проявляют, таким образом, противовоспалительные свойства.

\section{Катионы меди и цинка, хелатированные белками $\gamma$-глобулиновой фракции, в индукции выработки цитокинов макрофагально- моноцитарного ряда}

В развитии первичных реакций, опосредуемых клетками макрофагально-моноцитарного ряда, хелатирование $\mathrm{Cu}^{2+}$ трансформирует белки $\gamma$-глобулиновой фракции в состояние, сообщающее им способность индуцировать выработку КПК человека меньших, чем при воздействии исходных $\gamma$-глобулинов, количеств ИЛ-1 $\beta$. Присоединение $\mathrm{Zn}^{2+}$ увеличивает количество ИЛ-1 $\beta$, индуцируемого белками $\gamma$-глобулиновой фракции [9]. В эти же сроки наблюдения (24 ч индукции) на уровне раннего ответа белковый комплекс с $\mathrm{Cu}^{2+}$ индуцирует выработку КПК человека меньших, чем при индукции исходными $\gamma$-глобулинами, количеств ИЛ-6. Присоединение $\mathrm{Zn}^{2+}$ увеличивает количество ИЛ-6, индуцируемого $\gamma$-глобулинами [10].

Приведенная на рис. 3 схема взаимосвязей видится зеркальным отражением иллюстрации, представленной на рис. 2. Очевидно, что в отношении клеток макрофагально-моноцитарного ряда, запускающих первую фазу любого клеточного ответа и инициирующих воспаление, стабилизатор биомакромолекул $\mathrm{Zn}^{2+}$ и модифици- 
рованный им белок выступают индукторами выработки провоспалительных ИЛ-1 $\beta$ и ИЛ-6, тогда как деструктурирующий и дестабилизирующий Fc-фрагмент катион $\mathrm{Cu}^{2+}$ и хелатировавший его $\gamma$-глобулин ограничивают активацию клеток и выступают факторами противовоспалительной направленности. В сопоставлении, следовательно, реакций I типа иммунного ответа, опосредуемых Th1-лимфоцитами, с первой фазой (инициацией) воспаления, определяющейся активностью моноцитов и макрофагов, эффекторные свойства и действие катионов металлов и трансформированных ими белков $\gamma$-глобулиновой фракции меняются на противоположные (см. рис. 2 и 3 ).

Понятно, что в основе такой «смены знака» не могут лежать свойства собственно катионов: если металлы, сайты их связывания, белки, рецепторы клеток и внутриклеточные сигнальные пути по своей природе и характеристикам - одни и те же, то и ответ разных клеток на реализацию одной и той же последовательности включения сигнальных путей должен быть одинаковым. Полученный результат определяется, скорее, соотношением клеток, экспрессирующих различные типы Fc $\gamma \mathrm{R}$, соотношением порогов активации этих рецепторов, направленностью ответа - синтезом конкретного спектра цитокинов, в условиях которого индукция реакции должна находиться (или оставаться) под контролем механизмов, обеспечивающих исключение возможности повреждения собственных клеток и тканей организма человека.

Хорошо известно, например, что нейтрофилы экспрессируют более одного активирующего и ингибирующие Fc $\gamma \mathrm{R}$, на поверхности моноцитов и макрофагов обнаруживаются все типы активирующих Fc $\gamma \mathrm{R}$, мембрана НК-клеток экспонирует только активирующие Fc $\gamma R$. B динамике ответа цитокины, вырабатываемые Th1-лимфоцитами, усиливают экспрессию активирующих Fc $\gamma \mathrm{R}$ и снижают представленность на мембране клетки ингибирующих Fc $\gamma \mathrm{R}$. Th2-цитокины усиливают экспрессию ингибирующих Fc $\gamma \mathrm{R}$.

$\mathrm{B}$ физиологических условиях нормальной циркуляции свободного (гидратированного) $\mathrm{Zn}^{2+}$ в плазме всегда больше, чем $\mathrm{Cu}^{2+}$, которого там практически нет. Следовательно, в условиях случайного характера событий (а эквимолярное связывание белком металла - реакция, относящаяся именно к этой категории, она всегда случайна) обменные процессы преимущественно определяются $\mathrm{Zn}^{2+}$, индуцирующим посредством конформационных преобразований хелатирующего его белка развитие первой фазы иммунного реагирования (ИЛ-1 $\beta$, ИЛ-6, ИЛ-18) с последующим, в динамике I типа иммунного ответа, ограничением избыточной активации клеток (ИЛ-1 $\beta$, ИФН- $\gamma$ ) [7, 9-11]. Ионы $\mathrm{Cu}^{2+}$ тоже могут вносить определенный вклад в индукцию и ограничение (контроль) иммунного ответа в режиме физиологического реагирования. В первой фазе (инициация ответа) они преобразуют хелатирующие их $\gamma$-глобулины в конформацию, реализуемость в которой способствует усилению белком индукции (ИЛ-2, ИФН- $\gamma$ ) с одновре-

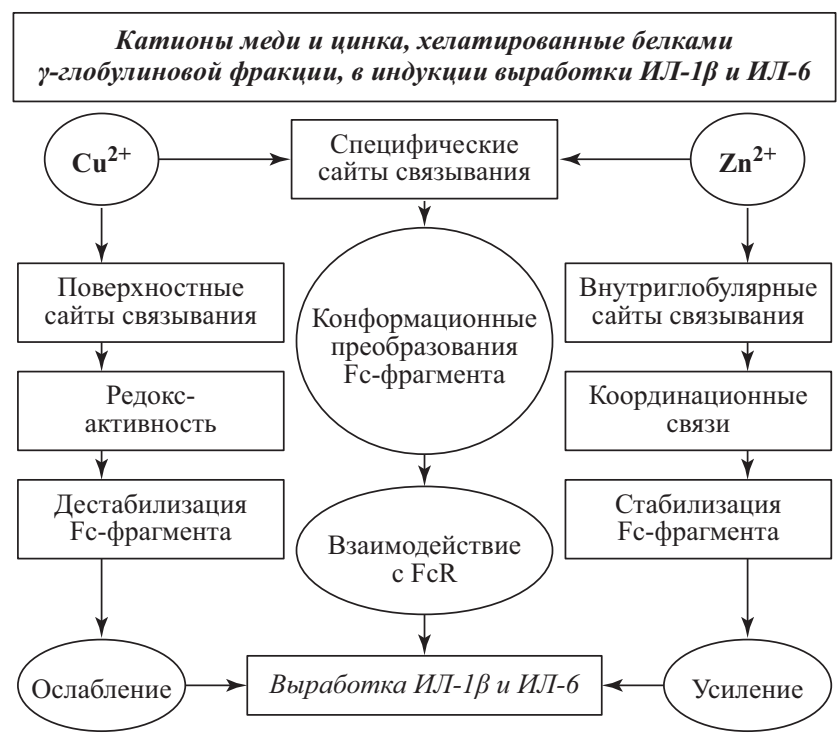

Рис. 3. Выработка ИЛ- $1 \beta$ и ИЛ-6 в присутствии белков $\gamma$-глобулиновой фракции, трансформированных связыванием $\mathrm{Cu}^{2+}$ и $\mathrm{Zn}^{2+}$

менным ослаблением индуцирующих эффектов $\mathrm{Zn}^{2+}$ (ИЛ-1 $\beta$, ИЛ-6) $[6,7,9,10]$. В динамике реакции благодаря эффектам связанных белком $\mathrm{Cu}^{2+}$ выработка цитокинов повышается, одновременно оставаясь ограничиваемой металлокомплексом с $\mathrm{Zn}^{2+}$ (ИЛ-1 $\beta$, ИЛ-6, ИФН- $\gamma)[7,9,10]$.

Тем самым, опосредуя в зависимости от конкретных условий микроокружения и циркуляции провоспалительную или противовоспалительную активность и реализуя индуцирующие или ограничивающие индукцию эффекторные свойства, белки $\gamma$-глобулиновой фракции плазмы, в режиме физиологического обмена случайно хелатирующие из периглобулярного пространства эквимолярные количества $\mathrm{Cu}^{2+}$ и $\mathrm{Zn}^{2+}$ и трансформируемые связыванием этих катионов, обеспечивают в иммунной системе физиологический регуляторный баланс, на основе которого может выстраиваться отвечаемость клеток в условиях форсированной антигенной или митогенной нагрузки.

Оппозитные свойства $\mathrm{Cu}^{2+}$ и $\mathrm{Zn}^{2+}$, транслируемые реципрокным действием преобразуемых ими $\gamma$-глобулинов, формируют в физиологических режимах и взаимодействиях определенный уровень напряженности клеточного иммунитета, необходимый для развертывания ответа в условиях форсированной индукции и ориентированный на осуществление антиген-независимых реакций, но вместе с тем рационально ограниченный и абсолютно достаточный в контексте исключения возможности срыва толерантности и повреждения собственных неизмененных клеток организма человека.

\section{Благодарности}

Автор выражает признательность научным сотрудникам Е.И. Востровой и М.А. Сарычевой за помощь, оказанную при подготовке рукописи к печати. 


\section{- Литература}

1. Чекнев С.Б. Сопоставление эффектов меди и цинка в условиях их взаимодействия с человеческим сывороточным $\gamma$-глобулином. Иммунология. 2006; 27 (4): 212-5.

2. Чекнев С.Б., Бабаева Е.Е., Голуб А.Е., Денисова Е.А., Воробьева У.А. Эффекты меди и цинка при связывании с человеческим сывороточным $\gamma$-глобулином. Медицинская иммунология. 2006; 8 (5-6): 615-22.

3. Чекнев С.Б., Денисова Е.А., Бабаева Е.Е., Воробьева У.А Монгуш Э.М. Конформационное состояние и антигенные характеристики $\gamma$-глобулина человека, модифицированного связыванием катионов меди и цинка. Иммунология. 2007; 28 (5) 274-80.

4. Чекнев С.Б., Ефремова И.Е., Денисова Е.А., Юшковец Е.Н Иммуноферментный анализ модифицированного катионами металлов $\gamma$-глобулина на низких концентрациях образцов. Российский иммунологический журнал. 2008; 2 [11 (1)]: 55-62.

5. Чекнев С.Б., Бабаева Е.Е., Денисова Е.А., Воробьева У.А., Монгуш Э.М. Антигенная специфичность образцов человеческого сывороточного $\gamma$-глобулина, полученных в условиях эквимолярного связывания катионов меди и цинка. Бюллетень экспериментальной биологии и медицины. 2007; 143 (2): 170-4.

6. Чекнев С.Б., Ефремова И.Е., Писковская Л.С., Мездрохина А.С., Юшковец Е.Н., Бабаянц А.А. Металлокомплексы человеческого сывороточного $\gamma$-глобулина индуцируют выработ- ку раннего ИЛ-2. Российский иммунологический журнал. 2012 6 [15 (2)]: 147-54.

7. Юшковец Е.Н., Ефремова И.Е., Бабаянц А.А., Чекнев С.Б. Динамика выработки интерферона- $\gamma$ в условиях индукции белками $\gamma$-глобулиновой фракции плазмы крови, трансформированными катионами металлов. Российский иммунологический журнал. 2010; 4 [13 (1)]: 41-7.

8. Чекнев С.Б., Григорьева Е.А., Николаева Т.Н., Пронин А.В. Бласттрансформация спленоцитов мышей в присутствии белков $\gamma$-глобулиновой фракции и их металлокомплексов с медью и цинком. Бюллетень экспериментальной биологии и медицины. 2010 150 (11): 555-8.

9. Чекнев С.Б., Ефремова И.Е., Писковская Л.С., Юшковец Е.Н., Бабаянц А.А. Выработка раннего ИЛ-1及, индуцированного металлокомплексами человеческого сывороточного $\gamma$-глобулина Бюллетень экспериментальной биологии и медицины. 2012; 154 (9): 326-9.

10. Чекнев С.Б., Ефремова И.Е., Мездрохина А.С., Бабаянц A.A. Оценка выработки IL-6 клетками крови человека в присутствии металлокомплексов $\gamma$-глобулина. Медицинская иммунология. 2012; 14 (6): 483-8.

11. Чекнев С.Б., Апресова М.А., Ефремова И.Е., Бабаянц А.А. Выработка IL-18 в присутствии металлокомплексов $\gamma$-глобулина Медицинская иммунология. 2013; 15 (1): 13-20.

\section{- References}

1. Cheknev S.B. Comparison of the copper and zinc effects during interaction of the metals with human serum $\gamma$-globulin. Immunologiya. 2006; 27 (4): 212-5. (in Russian)

2. Cheknev S.B., Babaeva E.E., Golub A.E., Denisova E.A. Vorob'eva U.A. The effects of copper and zinc ions during their binding with human serum $\gamma$-globulin. Medical Immunology. 2006; 8 (5-6): 615-22. (in Russian)

3. Cheknev S.B., Denisova E.A., Babaeva E.E., Vorob'eva U.A. Mongush E.M. Conformational state and antigen characteristics of human $\gamma$-globulin modified by binding the copper and zinc ions. Immunologiya. 2007; 28 (5): 274-80. (in Russian)

4. Cheknev S.B., Efremova I.E., Denisova E.N., Yushkovets E.N. Immuno-enzyme analysis of the $\gamma$-globulin which has bound meta ions, at the low samples concentrations. Russian Immunological Journal. 2008; 2 [11 (1)]: 55-62. (in Russian)

5. Cheknyov S.B., Babaeva E.E., Denisova E.A., Vorob'ova U.A., Mongush E.M. Antigenic specificity of human serum $\gamma$-globulin samples obtained under conditions of equimolar binding of copper and zinc cations. Bulletin of Experimental Biology and Medicine. 2007; 143 (2): 210-3. (in Russian)

6. Cheknev S.B., Efremova I.E., Piskovskaya L.S., Mezdrokhina A.S., Yushkovets E.N., Babayanz A.A. Metal complexes of hu-

\section{Сведения об авторе}

Чекнёв Сергей Борисович - д-р мед. наук, зам. директора по научной работе ФГБУ «НИЦЭМ им. Н.Ф. Гамалеи» Минздрава России, Москва, Российская Федерация

E-mail: cheknev@gamaleya.org

http://orcid.org/0000-0002-9512-7148 man serum $\gamma$-globulin induce production of the early IL-2. Russian Immunological Journal. 2012; 6 [15 (2)]: 147-54. (in Russian)

7. Yushkovets E.N., Efremova I.E., Babayanz A.A., Cheknev S.B. Dynamics of the interferon- $\gamma$ production after induction with human serum $\gamma$-globulins transformed by the metal ions. Russian Immunological Journal. 2010; 4 [13 (1)]: 41-7. (in Russian)

8. Cheknev S.B., Grigor'eva E.A., Nikolaeva T.N., Pronin A.V. Mouse splenocyte blast transformation in the presence of plasma $\gamma$-globulin fraction proteins and their complexes with copper and zinc. Bulletin of Experimental Biology and Medicine. 2011; 150 (5): 624-6. (in Russian)

9. Cheknev S.B., Efremova I.E., Piskovskaya L.S., Yushkovets E.N., Babayanz A.A. Production of early IL-1 $\beta$ induced by human serum $\gamma$-globulin metal complexes. Bulletin of Experimental Biology and Medicine. 2013; 154 (3): 343-5. (in Russian)

10. Cheknev S.B., Efremova I.E., Mezdrokhina A.S., Babayanz A.A. Evaluation of IL-6 production by human blood cells incubated with metal complexes of $\gamma$-globulin. Medical Immunology. 2012; 14 (6): 483-8. (in Russian)

11. Cheknev S.B., Apresova M.A., Efremova I.E., Babayanz A.A. Production of IL-18 in presence of metal- $\gamma$-globulin complexes. Medical Immunology. 2013; 15 (1): 13-20. (in Russian)

\section{Author's information}

Sergey B. Cheknev - MD, PhD, Deputy Director for Science, N.F. Gamaleya NRCEM of the MOH of Russia, Moscow, Russian Federation

E-mail: cheknev@gamaleya.org

http://orcid.org/0000-0002-9512-7148 


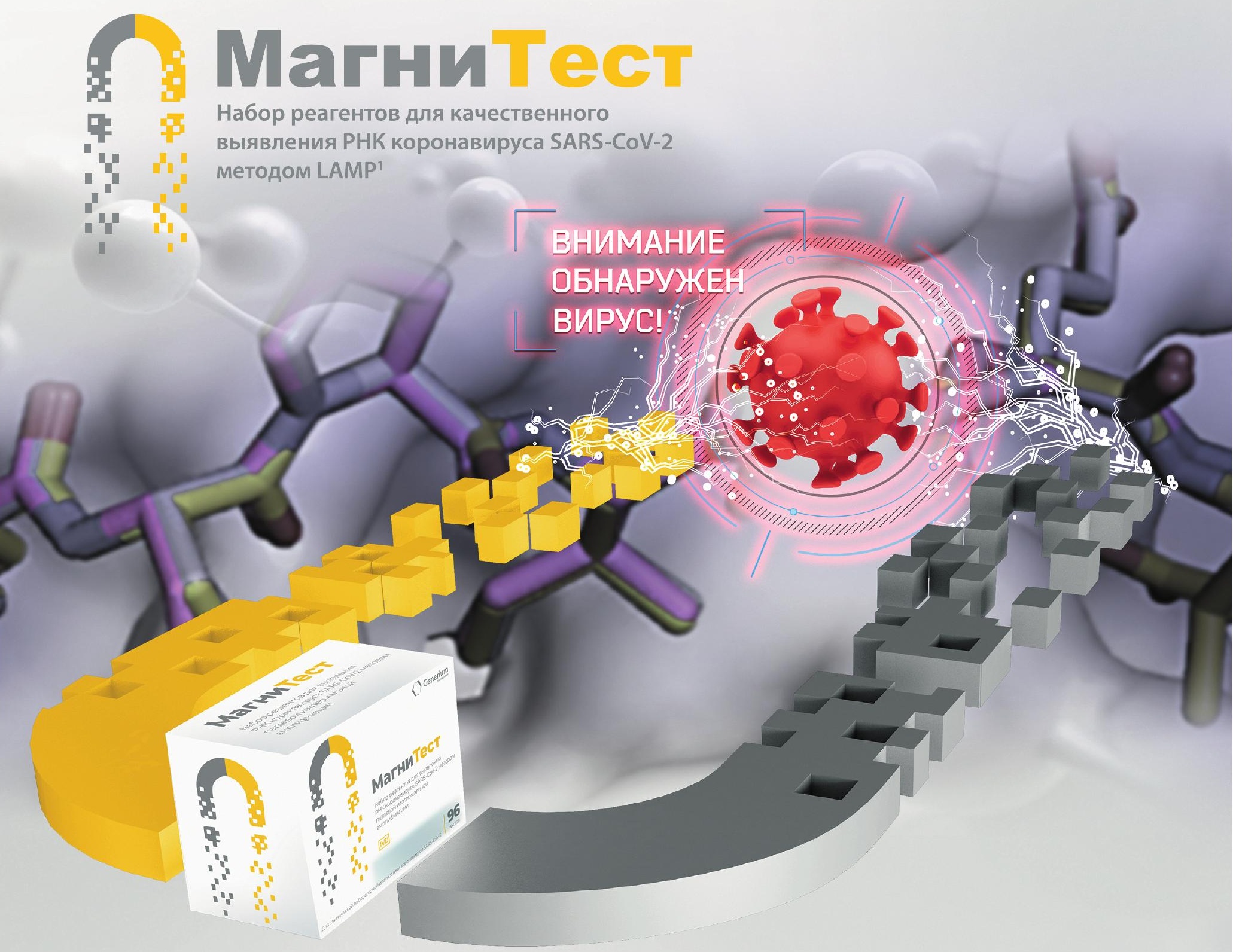

МЕТОД LAMP

МАГНИТНЫЕ ЧАСТИЦЫ

Проведение реакции при постоянной температуре 60-65을 благодаря использованию фермента Bst-полимеразы

Способствуют сокращению времени анализа ${ }^{2}$
Лизирование вируса и осаждение

PHК на магнитных частицах ${ }^{3}$

Может способствовать снижению количества ложноотрицательных результатов ${ }^{3}$

1. LAMP - Loop mediated isothermal amplification (англ.) - петлевая изотермическая амплификация. 2. Augustine, R.; Hasan, A.; Das, S.; Ahmed, R.; Mori, Y.; Notomi, T.; Kevadiya, B.D.; Thakor, A.S. Loop-Mediated Isothermal Amplification (LAMP): A Rapid, Sensitive, Specific, and Cost-Effective Point-of-Care Test for Coronaviruses in the Context of COVID-19 Pandemic. Biology 2020, 9 ,

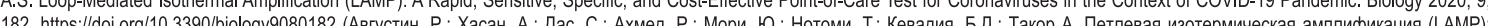
X быстрый, чувствительный, специфический и экономичный тест для лечения коронавирусов в контексте пандемии СОVD-19. Биология 2020, 9, 182.) 3. Инструкция по применению медицинского изделия для диагностики in vitro «Набор реагентов для выявления РНК коронавируса SARS-CoV-2 методом петлевой изотермальной амплификации «МагниТест»» по ТУ 21.20.23-096-26329720-2020 4. Notomi T, Okayama H, Masubuchi H, Yonekawa T, Watanabe K, Amino N, Hase T. Loop-mediated isothermal amplification of DNA. Nucleic Acids Res. 2000 Jun 15;28(12):E63. doi: 10.1093/nar/28.12.е63. PMID: 10871386; PMCID: PMC1027

Информация предназначена для медицинских специалистов. Перед применением ознакомиться с инструкцией по применению. АО «ГЕНЕРИУМ», 601125, Владимирская обл., Петушинский р-н, п. Вольгинский, ул. Заводская, строение 273.

РУ №P3Н 2021/14279 от 12 мая 2021 года 